\title{
高雄市の日本植民地時代における公園緑地計画の歴史 的展開
}

\section{Development of the City Parks and Open Space Planning of Kaohsiung, Taiwan, During the Japa- nese Colonial Period}

楊 平安* 平野 㑆三**

Pin-an YANG Kanzo HIRANO

摘要 : 本論文は，高雄市の日本植民地時代における公園緑地計画の展開を明らかにすることを目的と

し，文献及び公文書等の記録の検討並びに新たな資料の発掘により次の事項を明らかにした。

高雄市の公園緑地計画は，(1). 港湾都市として整備を開始する早い時点で最初に計画された公園が, 台北市の圓山公園と同じように市街地を展望する地点であること，(2).1917 年には土地利用計画に 合わせた公園の配置計画が立てられており，小学校に隣接した小公園及び河川沿いの緑道が計画され ていること，(3). 更に，大台北市区計画が立てられた同年には，ブールバールで結ばれた同様のパー クシステムが計画され，今日の高雄市の骨格を形成していること。

\section{1. 研究の目的}

高雄市は, 1920 (大正 9 ) 年 9 月の州制実施まで旧名の打狗之 呼ばれ, 1895 (明治 28) 年の日本統治以前は台湾南部の農漁村 集落にすぎなかった。1901（明治 34）年の人口は3,702 人であっ たが，1943（昭和 18）年末には人口 218,700 人となり，台湾の 第 2 の都市に成長した。日本植民地時代初期の台湾各地は, 衛生 状態が極めて劣悪だったため, 台湾の都市計画は既成市街地一帯 の市区改正として始められたのが一般的である。高雄市の場合は， (1)日本植民地時代初期に埋立地の港湾計画に併せて新市街地を造 成するなど，既成市街地の市区改正とはかなり違い，また，(2)植 民地 50 年の期間, 常に市区計画を先行させ, 都市の全体像の把 握から都市発展の方向を導く等の特色があった。そこで本研究は, 高雄市の公園緑地は, そうした計画性の溢れる新興都市によ゙のよ うに計画されてきたのか, 日本植民地時代における台湾の地方都 市における公園緑地計画の特色がどのように捉えられるのかを解 明することを目的としている。

関連する既往研究としては, 台湾の公園緑地については, 越沢 明 'が, 日本最初の公園系統が 1932 年の台北市区計画の中に表 れているこ之, 五島寧 ${ }^{2}$ が, 日本に公園道路が導入された起源は 1905 年の台北市区計画の「三線道路」であることを論じている が, 高雄市に関しては論じていない。また, 高雄市の都市計画に ついては, 黄武達 ${ }^{3)}$ が 1936 年の高雄都市計画について, 黄世 孟 ${ }^{4)}$ は台湾都市計画の変遷について, 点欽賢 は高雄市の発展及 び都市計画について, さらに蔡厚南 ${ }^{6)}$ は台湾の都市公園の建設及 び制度について述べているが, 高雄市の公園緑地計画の計画から 整備までの歴史的展開を論究したものではない。即ち, 本研究は まだ究明されていない高雄市の植民地時代における公園緑地計画の 歴史的展開について論究する研究として位置づけられるものである。

\section{2. 研究の方法}

本研究は主に日本と台湾の文献調查に基づき, 公園をとりまく 環境の变遷を整理し, それらの文献の解読を踏まえて高雄市の公 園緑地計画の時代的変遷を明らかにするとともに未紹介の史料を 発掘し, 特色ある公園計画の変遷を解明した。

\section{3．高雄市の都市計画の展開と公園緑地}

高雄市は1895（明治 28）年に日本領土となって以降, 築港計
画を拡大推進させながら都市形成を果たしてきた。このように港 湾の発展整備との関連を以て展開された高雄市の都市計画は 1908 (明治 41）年の打狗市区改正計画に始まり, 1912 (明治 45) 年の打狗市区拡張計画, 1917 (大正 6) 年の打狗市区計画変更, 1921（大正 10）年の高雄街市区計画拡張，1932（昭和 7）年の高 雄市市区計画変更, 1936（昭和 11）年の高雄市市区計画及び 1938 （昭和 13）年の高雄市都市計画地域決定之続いた。これら の計画の中での公園緑地の扱いについて分析した。

\section{（1）市区計画前の打狗港湾調査}

高雄港（旧名打狗港）は，高雄湾（打狗湾）の湾口にあり，港 内の水深は浅く, その大部分が干潮面下 $1 \sim 2$ 尺（約 $0.3 \mathrm{~m} \sim 0.6$ m）に過ぎなかった。1899（明治 32）年 9 月に民政長官後藤新 平は南巡の際, 高雄を視察して港湾調查の実施を決定した。1900 （明治 33）年 6 月から 1901（明治 34）年 2 月まで, 調査費 7,800 円を以て初の港湾調查が行われた ${ }^{7}$ 。

1899 （明治 32）年に台湾総督府は台湾縦貫鉄道計画を定め, 同年 8 月に打狗より台南に向かって起工し, 翌 1900 （明治 33） 年 11 月に台南・打狗間に鉄道が開通した ${ }^{8)}$ 。これに伴い, 1904 （明治 37）年に鉄道部は打狗停車場を拡大するため, 干潟地 4 万 坪（約 13.2ha）の埋め立てを議決している。総工費 25 万円の 4 力年工事として同年 6 月に着手して 1908 （明治 41）年 3 月に 13.2ha の埋立地が完成した 浚渫土砂による市街地造成である。

1905（明治 38）年から 1906（明治 39）年末にかけて，総督府 土木局は 2 万 5 千円の経費で 2 回目の港湾調査を行った。浚渫し た土砂で鉄道敷地の西北に 8 万坪（約 26.4ha）の埋立地を造成 した ${ }^{10\rangle}$ 。因みに打狗港の貿易額は 1896 （明治 29）年の 68 万余円 から 1907 (明治 40) 年の 1,180 万余円と 11 年間で約 17.3 倍に 成長した。

\section{（2） 1908 年の打狗築港計画及び市区改正計画}

1908（明治 41）年 3 月に総督府は打狗港の貿易の進展に鑑み, 打狗築港計画を立案した（図ー 1$)^{11)}$ 。計画の主な内容は，(1) 岸 壁に三下トン以下の船舶 10 隻の係留を可能とし，一年間の取扱 貨物の目標を 45 万 3,500 トン (1910 年 3 月に 35 万トンに変更) とする。(2)港内に水域面積 $56.2 \mathrm{ha}$ の航路を干潮面下 24 尺（約 $7.3 \mathrm{~m}$ ）の基準で浚渫する。その北岸に長さ $1,164 \mathrm{~m}$ の岸壁を築造 する。(3) 5 つの繋船浮標を設け，4隻の船舶の係留を可能とする。

*東京農業大学大学院農学研究科 **東京農業大学地域環境科学部造園科学科 
(4)岸壁背面には船溜を設けることであった。この築港計画は総 $\mathrm{T}$ 費 473 万 3 千円の 6 力年事業として 1908 （明治 41）年 4 月 1 日 に着手した ${ }^{12)}$ 。1910（明治 43）年 3 月に総督府は財政事情を検 討し, 再審議の結果, 5 力年事業に変更し，1912（明治 45）年 に築港計画事業は完成した。

総督府土木局は打狗築港計画に応じて打狗市区計画を立案した。 1908 (明治 41）年 5 月 1 日に鳳山庁告示第 29 号により「打狗市 区改正計画」が公布された ${ }^{13)}$ 。この計画人口は 42,000 人で，面 積は約 172ha であった（図一-1)。計画の主な内容は，(1)街路網 は碁盤型で 3 種類の分類を持ち，(2)道路幅は 5 間（約 $9.1 \mathrm{~m}$ ) と 10 間（約 $18.2 \mathrm{~m}$ ）の 2 種類に分けられ (14) $^{14}$ (運河 2 本, (4)岸壁 1 本，(5)公園 1 力所（打狗山麓）が初めて計画されている。

1908（明治 41）年に市区改正計画の岸壁工事が着手してい る ${ }^{15)}$ 。これに伴い, 哨船頭干潟地を埋め立て, その面積約 23.1ha の区域を市街地予定地とした。またその西側に長さ 800 $\mathrm{m}$ の運河を設け，中心市街地との交通の便を図った。そして 1909 （明治 42）年 10 月に打狗整地会社を設立し，同 社は打狗築港裏岸壁に沿った一帯の塩田を買收し，市 街地化に向けた埋立工事に着手した。1914（大正 3 ） 年に当該工事は完成し, $61.2 \mathrm{ha}$ の土地が造成され た ${ }^{(6)}$ 。

$1910 （$ 明治 43）年 7 月に打狗上水道計画が立案さ れた。これは計画給水人口 5 万人（内に船舶用水 1 万 人), 工費 130 万円を以て着工し ${ }^{17} ， 1913$ (大正 2 ) 年 4 月に竣工した。この上水道の配水池は打狗山鹿に 位置し，これは 1908 年に計画された公園の位置に一 致している ${ }^{18)}$ 。

\section{（3） 1912 年の打狗築港拡張計画及び市区拡張計画}

1911（明治 44）年に高雄港の取扱貨物量は 44 万卜 ンを超え, 1908 年の計画目標より大幅に上回ってい る。総督府土木局は 1912 （明治 45）年 3 月に高雄港 拡張計画を立てて 1,278 万 4 千円を計上し，1912 年 度から 10 力年計画として準備工事に着手した ${ }^{19)} 。 こ$ の計画は，(1)年間 90 万トンの取扱貨物を目標とし， 岸壁に 1 万トン以下の船舶 10 隻の係留を可能とする。 (2)港内に於いて干潮面下 30 尺（約 $9.1 \mathrm{~m}$ ）まで水深 を深くし，水域面積約 $119 \mathrm{ha}$ まで浚渫する。(3)既設 岸壁を増築し, 総延長 $1,327 \mathrm{~m}$ とする内容としていた。

総督府土木局は打狗築港拡張計画に応じて打狗市区 拡張計画を策定した。1912（明治 45）年3月19日に 台南庁告示第 22 号により「打狗市区改正計画の一部 変更」が告示された（図一 2$)^{20)}$ 。この計画は面積 320ha で, 計画区域は 1908 年の計画を東へ向かって 高雄川まで拡張したものである。計画内容は, (1)街路 網は前回と同じであったが，道路幅は 15 間（約 27.3 m) のものが加わり, (2)湊町西側の運河の縮小, (3) 2 本の橋梁計画であった。

\section{（4） 1917 年の打狗市区計画}

打狗築港計画事業の進渉, 埋立地の概成, 人口之工 場の増加，打狗港の貿易成長等によって，1917（大正 6 ）年末に総督府土木局は打狗市区計画を定めてい る ${ }^{21)}$ 。この計画は市街地区域面積の算定が 1 人当たり 15 坪 (約 $50 \mathrm{~m}^{2}$ ) を基準としているため, 計画人口を 37,000 人に修正した。道路計画は河岸通り 15 間（約 $27.3 \mathrm{~m}$ )，幹線道路 10 間（約 $18.2 \mathrm{~m}$ )，その他 5 間 （約 $9.1 \mathrm{~m} ）$ としているが, 眺望を重視した展望道 2 本が追加されたのが特長である(図一 3 )。地域地区 は商業区・工業区・住宅区・特殊区の 4 区に分けられ，
商業区は塩埕埔幹線道路に沿い，工業区は風下側で，水陸運に便 なる所を選定する。住宅区は普通住宅区之商業住宅区に分け, 後 者は商業区を兼用するものとする。

1908 年に計画された打狗山の公園が配水池に占用されている ため官公庁用地に变更され，その周辺一帯は新たに公園として指 定された。公園緑地計画は, 計画書では埋立街区の三角ブロック に緑園を点設したとしているが, 計画図には, 打狗山を含めて 7 公園 (北野町 2 力所, 塩町 2 力所, 堀江町 1 力所, 湊町 1 力所, 山手町 1 力所）が工業区を除き, 計画的に配置されている（図一 4 )。また, 打狗川船入場沿岸 15 間道路及び運河沿岸には緑樹帯 を設け, 遊歩道を兼衫る内容となっている。

\section{（5） 1921 年の高雄街市区計画変更}

1920 (大正 9 ) 年 9 月の州制実施により,「打狗」は「高雄」 に改称された ${ }^{22)}$ 。高雄市の人口は 1920 年に 35,404 人に増加し, 1917 年の計画人口に迫っている。こうしたことを背景に, 高雄 州知事は総督府に敦申し ${ }^{23)}$, 台湾市区計画委員会の審議を得て

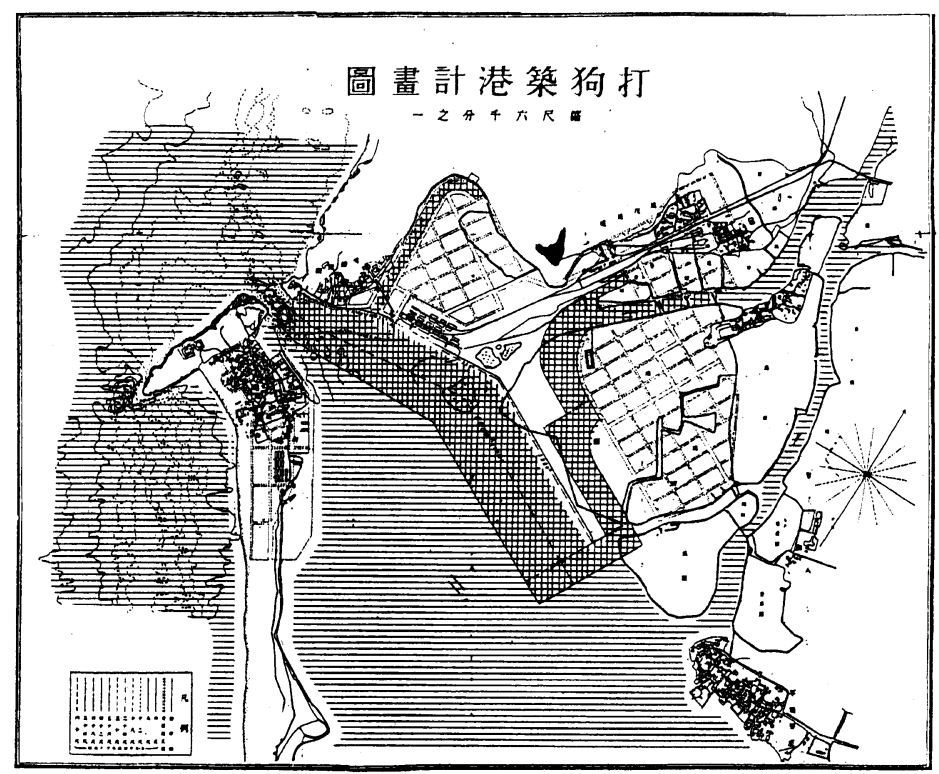

図-1 1908 年の打狗築港計画図公園曲浚渫区域 注. 韦区改正計画図はこの図面から海面と浚渫区域を除いた図面である。

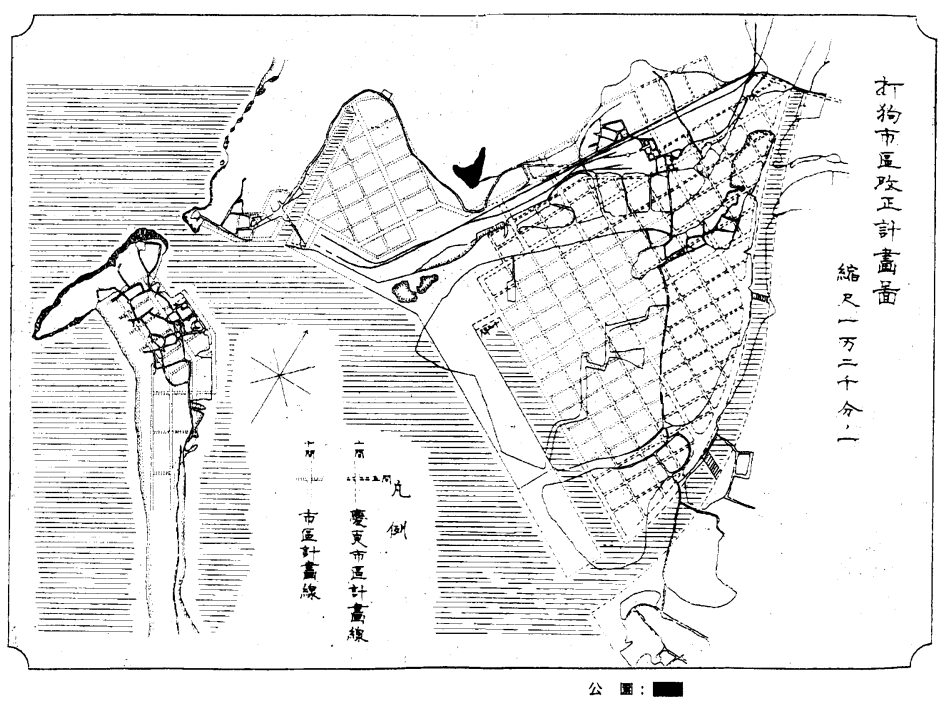

図－２１912 年の打狗市区改正計画図 
1921（大正 10）年 2 月 13 日の高雄州告示第 19 号「高雄街市区 計画変更」がなされた 計画人口 116,000 人である。計画区域面積は $900 \mathrm{ha}$ で, その区 域は東側の高雄川を越えて前金及び苓雅寮の一部にまで拡大して いる。計画内容は，(1)道路計画では幅 $5 ・ 10 ・ 15$ 間の他， 3 間道 路の追加。(2)商業区を哨船頭から塩埕区に移し，工業区を苓雅寮 に配置した。(3)計画区域の東側には幅員 25 間 (45.5m) の緑地 帯が計画された（図一 5$)^{25}$ 。

この計画は高雄川西側の沿岸道路設計変更のため, 1917 年に 計画された三角ブロックの緑園が廃止された。また，高雄州は， 人口の増加及び高雄の発展を勘案して市区計画区域を拡張し, 州 庁を高雄川東側に移転するため, 1917 年に計画された官公庁予 定地の移転を中止し，それに伴って隣接した緑園も廃止した。

1923 (大正 12）年 4 月 21 日に皇太子殿下が高雄を訪れ, 誕生 日を高雄山で過ごした。それに因み, 総督府は高雄山を寿山と命 名し ${ }^{26)}, 1923$ 年度予算に寿山記念公園造営設計費 3,726 円を計 上した上で27)，1924（大正 13）年1月に本多静六博士を招いて 寿山公園の計画・設計を依頼した ${ }^{28)}$ 。本多は森林公園の 構想として自動車道路, 遊歩道, 大展望台, 散歩道, 果 樹園, 高雄神社等を提案した。寿山公園計画事業は 1924 年 12 月に着手し, 1929 (昭和 4) 年 4 月に開園し た。

1928（昭和 3）年に高雄州は御大典記念事業として高 雄市に 7 つの公園を決定し, 1929 （昭和 4) 年度より公 園整備に着手している ${ }^{29)}$ 。それらは 1929 年度の寿町公 園（寿町 27 番地， $1,488 \mathrm{~m}^{2}$ ) と入船町公園（入船町 1 丁 目, $1,296 \mathrm{~m}^{2}$ ), 1930 年度の湊町公園 (湊町 3丁目, 1,488 $\mathrm{m}^{2}$ ), 1931 年度の北野町公園 (北野町 4 丁目, $1,759 \mathrm{~m}^{2}$ ), 1932 年度の西子湾公園 (寿町 1 丁目, $985 \mathrm{~m}^{2}$ ) 之哨船町 公園 (寿町 1 丁目, $1,428 \mathrm{~m}^{2}$ ) 及び 1933 年度の緑町公園 (緑町, 57,868 $\mathrm{m}^{2}$ ) である(図-6 ( $^{30)}$ 。

\section{（6） 1932 年の高雄市区計画変更}

1928（昭和 3）年から 1941（昭和 16）年にかけて高 雄港の貿易額が台湾全島の 42.3\%〜 46.7\%を占め, 高雄 市は益々発展した。1926（大正 15）年 12 月に高雄州は 施設事項調查委員会規程を定め, 委員会を組織し, 公園, 道路，市区計画，上水道，河川，水利とその他に関する 事項の計画並びに番議の権限を与えた ${ }^{31 !}$ 。委員長は州知 事が勤めた。翌1927（昭和 2) 年 8 月から同年 12 月に かけて，高雄州知事太田吾一は市区計画区域を拡張する ため，高雄川東側の前金，苓雅寮，過田仔，大港埔，林 徳官, 大港, 戯獅甲 (その大部分は農地, 苓雅寮・戯獅 甲の一部は低湿池）の測量を実施した ${ }^{32)} 。$

1931（昭和 6 ）年 6 月に高雄州宁が前金 (高雄川東側) に移転したことを機として高雄市域の拡大計画が着手さ れた。1932（昭和 7 ）年 10 月 10 日に高雄州は台湾市区 計画委員会の審議 ${ }^{33)}$ を経て告示 190 号により市区計画変 更を行った した新計画である。しかし, 計画が告示された時点には, 南側の軍事施設用地, 海軍飛行場, 工業地域, 交通幹線 道路などが未だ明確になっていなかったため，決定され た計画内容の一部のみが先に告示された ${ }^{35)} 。$

この計画は新築州庁を中心とし, 計画面積は 581.73 ha, 計画人口は 312,000 人, 1 人当たり市街地所要面 積 $80 \mathrm{~m}^{2}$ を基準としている。主な内容は，(1)前金・苓雅 寮（高雄川東側）一帯の街路系統を碁盤目状に一体調整 したこと。(2)道路網を見直し, 中央に公園道 1 本を配置 したこと（図一-6)。(3)栄町にある幹線道路沿いに官公
署用地を指定したことの 3 点を特徴としている。

1933 (昭和 8 ) 年 6 月に計画区域の東側に野球グラウンド ${ }^{36)}$ （4.2ha）が整備されたが，1936 年の計画により廃止された。

（7） 1936 年の大高雄都市計画

1936（昭和 11）年8月 29 日に高雄州は, 台湾市区計画委員会 の審議を経て ${ }^{37}$, 告示第 114 号により高雄市区計画変更を行っ た ${ }^{38)}$ 。この計画は1932 年の計画において保留された部分を含め て告示し, 計画の一部改正も行われた。計画区域面積は 4,623.3ha であり, 計画人口は 40 万人に修正された。計画目標 年を 30 年後の 1965 年としている。その計画内容は, (1)高雄駅の 建設, (2)計画学校用地 10 筒所, (3)道路系統 4 種類（主要幹線道 路, 幹線道路，区画道路，公園道），(4)公園緑地計画としている。

公園計画は，中央公園 $10.8 \mathrm{ha}$ (前金)，運動公園 $11 \mathrm{ha}$ (戯獅甲), 運動公園 30ha（林徳官），熱帯植物園 65ha（大港）及び普通公 園（三塊厝）の 5 大公園及び 23 小公園を計画し，公園間の配置 基準を $500 \mathrm{~m}$ 以内としている。小公園は殆どが学校予定地に隣接 している。幅 $60 \mathrm{~m}$ の公園道が 3 本計画され ${ }^{39} ， 5$ つの計画大公

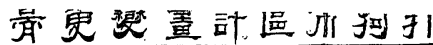

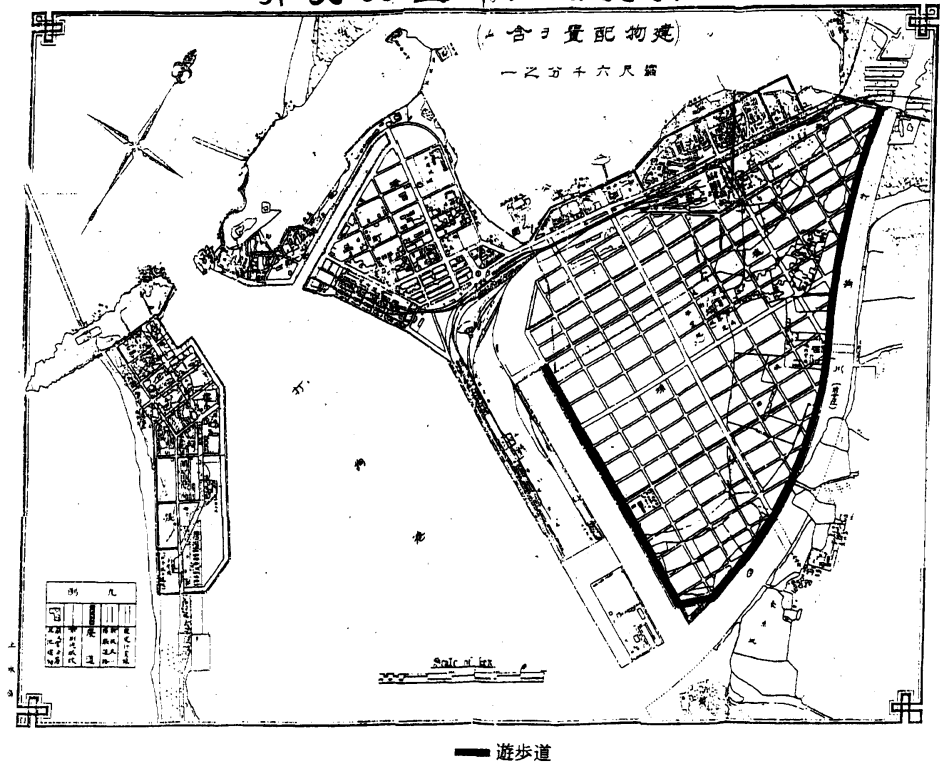

図ー 31917 年の打狗市区計画変更図

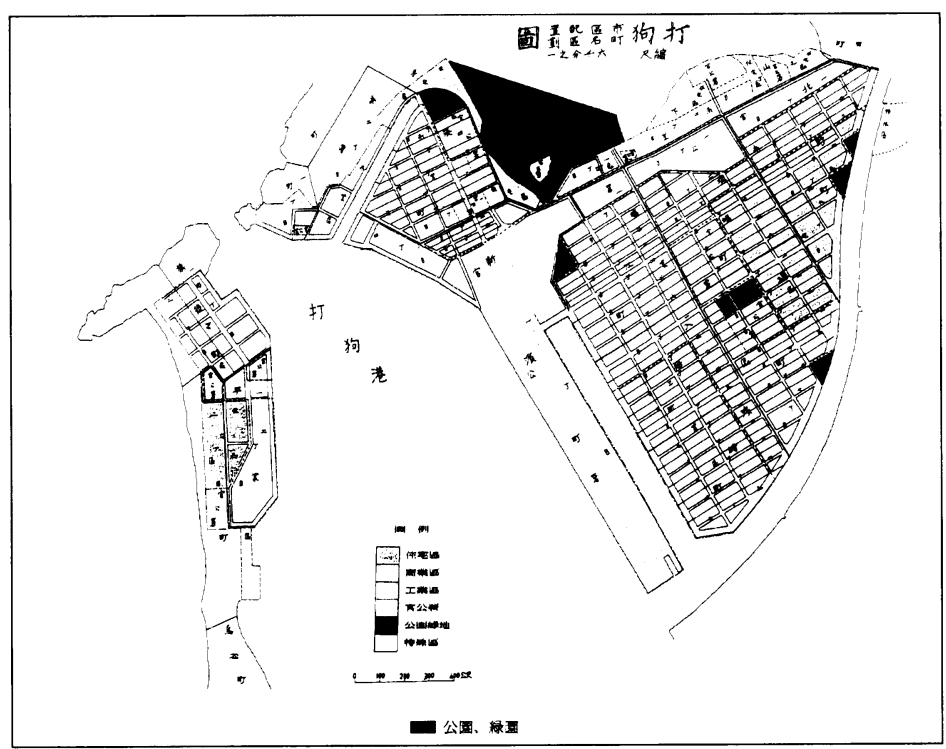

図一 41917 年の打狗市区配置町名区画図 
園はこの公園道で連絡し，ネットワークが形成されている（図一 7 )。その他，高雄川上流の汾岸地帯には緑地が設けられている。 高雄駅前及び駅裏にはそれぞれ 3 ha と 1.5 ha の広場を設けてい る。幹線道路の交差点に直径 $100 \mathrm{~m}$ から $150 \mathrm{~m}$ の円形広場緑地が 設けられている。公園緑地計画面積は公園道を含めて約 $206 \mathrm{ha}$ （寿山公園を除く）であり, 計画区域面積の $4.45 \%$, 計画人口一 人当りの公園緑地面積は $5.15 \mathrm{~m}^{2}$ であった。

この計画が告示された 2 年前の 1934 (昭和 9 ) 年 12 月に, 高 雄市長松尾繁治は, 市政施行 10 周年記念事業として「大 高雄完成方策」の懸賞論文を公開募集した。それは 1932 年に告示された市区計画をどのように引き続いて発展して いくのかを有識者に求めることを目的としていた。応募さ れた論文の中から，優秀論文の 6 編が選ばれ，「大高雄建 設論と市の現勢」として出版された ${ }^{40)}$ 。一等入選者岡山登

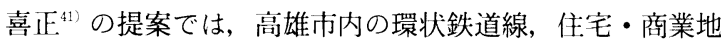
域の候補地の選定, 高雄駅の移転など，二等入選者陳高 昂 ${ }^{42)}$ の提案では, 中央公園・運動公園の設置，公園系統な どが計画されている。

1936 年に計画された大公園の内, 1937 （昭和 12）年 8 月に総督府告示第 185 号により戲獅甲にある運動公園の位 置が変更されだ3)。

（8）1938 年の高雄市都市計画地域決定とその後の都市計 画変更

1938 （昭和 13）年 11 月 26 日の総督府告示第 408 号に より高雄市都市計画の用途地域が定められた ${ }^{44)}$ 。この計画 の主な内容は, (1)商業地域 838.5ha（市域面積の 18.1\%） を，幹線道路の両側に沿っておおよう市の中心部に配置す る。(2)工業地域 676.6ha（同 14.6\%）を，市の外縁に面的 配置する。(3)住居地域 912.5ha（同 19.7\%）は，商業地域 に挟まれた地区之工業地域に接する地区に配置する。(4)末 設定地域 177.7ha（同 3.8\%）を，工業地域に隣接させる。 (5)無設定地域 2,018ha（同 43.7\%）は, 北側に配置する。 この用途地域指定は 1937 年の都市計画令施行以来, 台湾 で初めての地域地区計画であった。

1936 年の公園緑地計画と合わせてみると, 公園緑地面 積は無設定地域（農業地域）を除くと計画面積の $7.9 \%$ を 占めている。工業地域之他の土地利用地域は幹線道路によっ て区分されている。

その後の主な都市計画変更としては，1941（昭和 16） 年 8 月に縦貫道路が高雄駅の東側に変更されたため, 第 2 号と第 1 号の公園道の交差点の北側の公園道が廃止された。 その代わりに大港から林徳官まで幅 $30 \mathrm{~m}$ の 4 号公園道が 新設された ${ }^{45}$ )。1943（昭和 18）年 11 月に戯獅甲・栄町に 3 つの小公園が計画され，前金では幅員 $30 \mathrm{~m} の 5$ 号公園 道が追加された ${ }^{46}$ 。

1936 年の大高雄都市計画が告示されて以来, 都市計画 事業は主に高雄駅を中心とした開発であった。高雄駅新設 事業は1936 年に用地買収が始まり ${ }^{47)}, 1937$ (昭和 12）年 に工事着手して 1941（昭和 16）年 6 月に竣工した 1937 年に日中戦争に入り, 財政難と人員不足のため, 1945 年までの都市計画事業は高雄駅を中心とした 6 本の 幹線道路 $(1 \cdot 5 \cdot 6 \cdot 11 \cdot 14 \cdot 39$ 号 $)$ を優先に整備された。 1936 年に計画された公園と公園道の整備は見られなかった。

土地区画整理事業として，1937（昭和 12）年 6 月に総 督府は第 1 号地区（高雄駅前の前金, 大港埔, 三塊厝, 大 港の各一部, 面積 101.86ha）及び第 2 号地区（高雄駅前 の前金, 三塊厝, 大港埔, 過田仔, 戯獅甲，苓雅寮の各一 部，面積 463.4ha，追加を含む）を告示した ${ }^{49}$ 。1938（昭
和 13）年 5 月の第 1 号地区は, 総督府の認可着手後, 換地が終 了した段階で終戦を迎え, 広場用地（2.55ha）が確保された。 1942 （昭和 17）年 11 月に第 2 号地区の一部（72.5ha）が認可施 行され，その認可施行された一部は換地完了した段階で終戦を迎 え, 公園用地 $1.87 \mathrm{ha}$ を確保した ${ }^{50)}$ 。

\section{4. 考察}

日本植民地時代における高雄市の主な公園緑地計画の内容と整

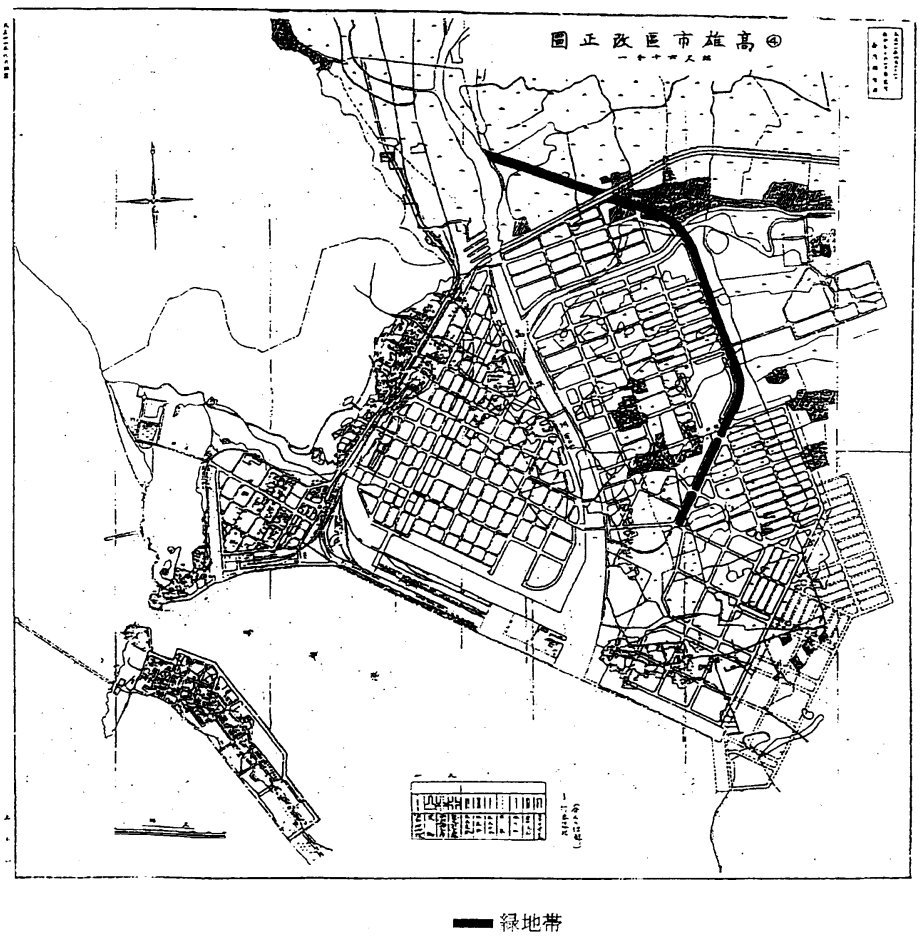

図－５１921 年の高雄市市区改正図

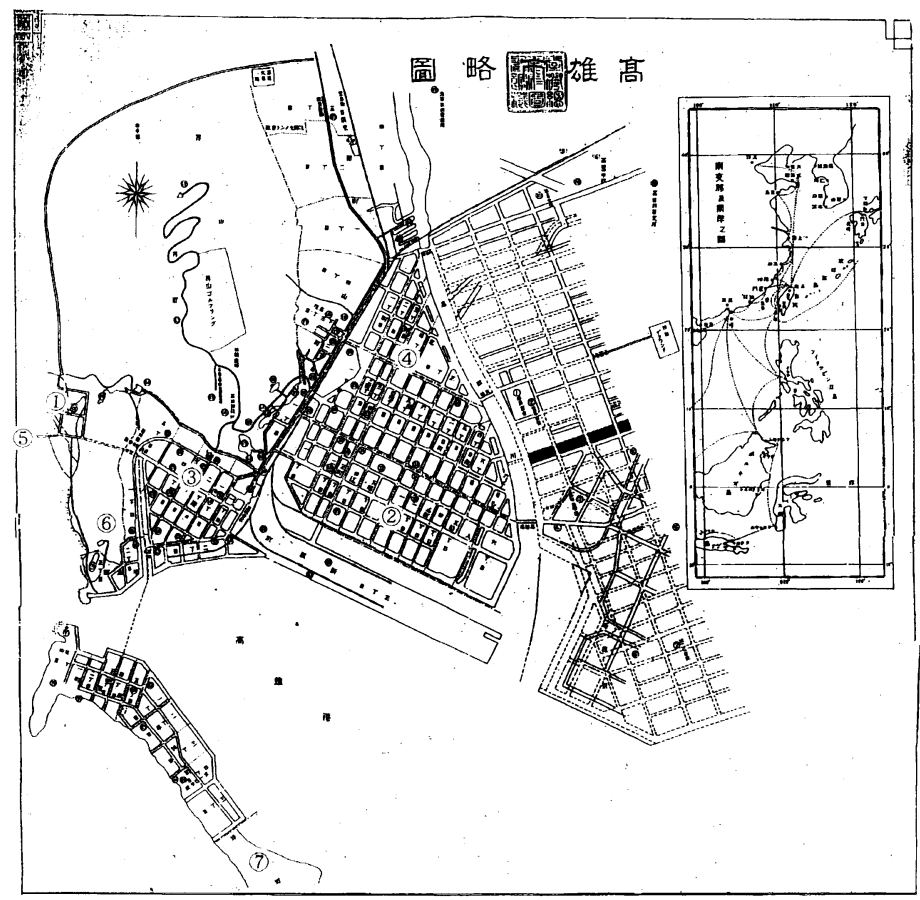

（1)寿町公園、(2)入船町公園、(3)潜町公園、(4)北野町 公園、(5)西子湾公園、(6)哨船町公園、(7)緑町公園 公園道

図－６１933 年の高雄市略図 
備状況は表一1のように整理されるが，こうした歴史的変遷を通 じて, 都市計画の展開とそれに対応する公園緑地計画の変遷を考 察すると次のようになる。

（1）1895 1907 年 公園無計画期（市区改正計画策定前期）

農漁村集落であった高雄に, 港湾としての適地性を見出し, 港 湾の調査及び建設に着手している。1904（明治 37）年の鉄道部 の打狗停車場拡大計画之 1905 （明治 38）年の土木局港湾調查が 併行してなされ，これらにより浚渫された土砂の接岸荷役設計が あり，高雄に経済活性化上巨大な利益をむたらした。その結果と して築港計画に伴う市区計画の必要性と急迫性が生じた。

（2）1908１916年 公園単独計画期（港湾計画に伴う市街地整 備期)

大規模な港湾計画とその浚渫事業に併せて，市街 地の整備が必要となり, 市区計画を策定している。 しかし，その内容は港湾施設の他，鉄道，道路の基 盤整備に止まっている。公園は景勝地を単独指定し ているのみである。

1912 （明治 45）年の市区拡大計画は, 1908 年々 同様，打狗港拡張計画に対応した計画であるため， 埋立予定地の都市施設は計画道路しかなかった。

（3）1917 1931 年 公園分散配置期（土地利用計 画策定初期)

商業区，工業区，住宅区，特殊区の 4 区分に分け, さらに住宅区を普通住宅区之商業住宅区に分けて計 画しており, 都市計画としての初期の形態が整えら れた。

1917 (大正 6 ) 年の計画は, 1912 年計画の新市 街地（埋立予定地）が完成する前に，都市施設を補 完する計画だと窥える。計画図から読み取ると,こ の公園緑地計画は，（i ）。埋立地の中央に「官公署」 に隣接するように公園が配置されており，中央公園 としての位置付けが考察される。（ii）。公園は住宅 区之商業区に分散するように配置されている。また, 小学校に隣接する公園が見られることは, 関東大震 災以前に既に意龱的に計画配置された公園があった ことを示している。（iii）。沿岸道路（幅員 $27.3 \mathrm{~m}$ ) 2 本の内, 「河岸通」は高雄・鳳山間の主要幹線道 路として計画されたが, 高雄川沿岸通りは高雄・台 南間の幹線道路ではないため「遊歩道」を兼ねた道 路として計画されており，公園道の一つと考えられ る。（iv）. 高雄山麓の公園が拡張されているのは, 計画公園が高雄上水道の配水池に占用されたことと, 優れた景勝地の保全を図ろうとしたためと考えられ る。（v）。この地域地区を前提とした公園緑地の配
置は, 1919 (大正 8 ) 年に日本で実施された都市計画法の地域地 区制より一足早い時点であることは特筆できる。

1921（大正 10）年の計画では，高雄川の東側に緑地帯が計画 されたが, 1932 年の計画により廃止された。高雄川河口付近の 苓雅寮沿岸地带には，この計画の道路系統がまだ生かされている。

1924（大正 13）年から整備が始められた寿山公園は，史蹟名 勝として扱われ, 高雄市役所の市区計画事業でも公園として位置 づけられていない垃。土地利用も保安林 ${ }^{52}$ であるため，自然公園 的な性格之言える。

\section{（4）1932 1945 年 公園系統確立期（大高雄都市計画期）}

大高雄都市計画は, 1932 (昭和 7 ) 年の告示で既に「公園, 公 園道並二緑地 $\ni$ 適当ナル位置二配置シ・・現在ノ市発展/情勢

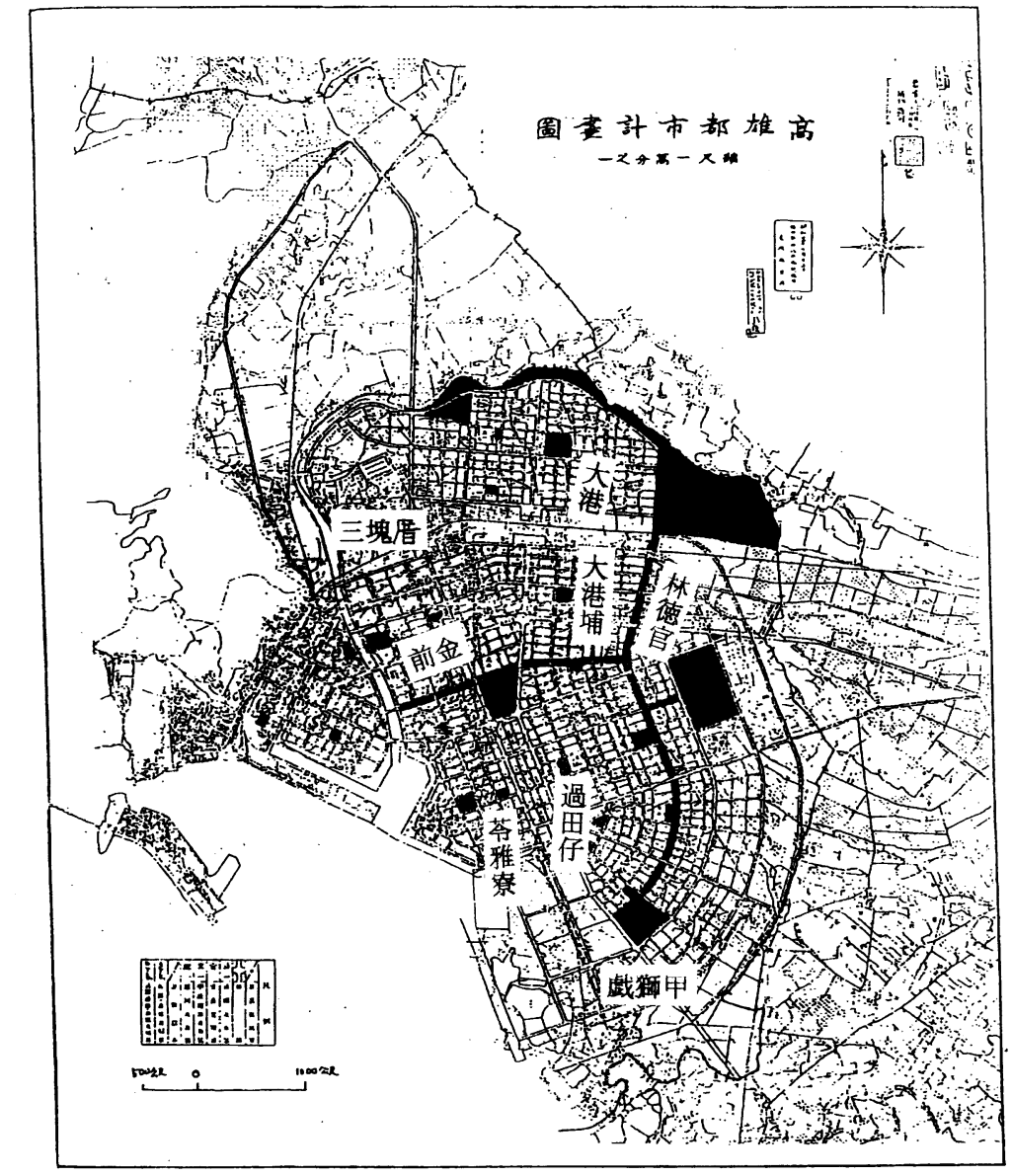

公園道、公園

図ー 71936 年の高雄都市計画図

表一 1 日本植民地時代における高雄市の主な公園緑地計画の内容と整備状況

\begin{tabular}{|c|c|c|c|}
\hline 計画年 & 計 画 名 & 公園緑地計画内容 & 備 \\
\hline 1908 & 打狗市区改正計画 & 打狗山公園1力所を計画 & 1910年に配水池として占用 \\
\hline 1912 & 打狗市区拡張計画 & （1908年の計画に変更なし） & \\
\hline 1917 & 打狗市区計画変更 & $\begin{array}{l}\text { 1908年に計画された公園を菅公庁用地に変更 } \\
\text { 新たに公園1力所、緑園6力所計画 }\end{array}$ & $\begin{array}{l}\text { 緑園6力所は1921年の市区計画変更により廃止 } \\
\text { 整山備、1929年開園 }\end{array}$ \\
\hline 1921 & 高雄街市区計画変更 & 計画区域の東側に緑地帯を計画 & 1932年の市区計画変更により廃止 \\
\hline 1928 & 御大典記念事業 & 高雄市域内に公園7力所を決定 & 1929～1933年に公園7力所は整備、開園 \\
\hline 1932 & 高雄市区計画変更 & $\begin{array}{l}\text { 抎張された計画区域の中央に公園道1本を計 } \\
\text { 䛲 }\end{array}$ & \\
\hline 1936 & 大高雄都市計画 & $\begin{array}{l}\text { 5大公園、23小公園、公園道3本（1932年の } \\
\text { 計画含む)-を計画（総面積206ha) }\end{array}$ & $\begin{array}{l}\text { 1942年より第2号地区土地区画整理の一部施行により公 } \\
\text { 園用地1.87haを確保 }\end{array}$ \\
\hline
\end{tabular}


二鑑ミ最モ急 要スルト認メラルル区域二亘リ本計画,一部 定セントスルモ/ ${ }^{53)}$ とされ，1936 年の都市計画の公園道が既に 一部計画されていることから，1932 年からを公園系統確立期と する。

1936 年の公園緑地は主として住居地域に配置されている。 1936 年と 1938 年の計画を合わせて見ると, 住宅地の環境を考虑 して公園道が計画されているが，異種土地間の緩衝緑地の機能を 考慮した公園緑地の配置の考え方は見られない。また，台北市が 1932 (昭和 7 ) 年に大台北市区計画が告示され，1941（昭和 16） 年 11 月にようやく用途地域指定が告示されたことに比べると, 高雄市は地域地区に合わせた公園緑地配置計画が早い時点で行わ れており，その意義は極めて大きい。

\section{5. まとめ}

以上のように高雄市の公園緑地計画は, 公園計画が市てられて いなかった時期も含めて 4 つの時期に時代区分できたが，同時に， (1)港湾都市として整備を開始する早い時点で最初に計画された公 園が, 台北市の圓山公園と同じように市街地を展望する地（後の 寿山公園の一角）に位置していること。(2)1917 年には土地利用 計画に合わせた公園の配置計画が立てられ, かつ, 小公園が小学 校に隣接して計画されていること, 河川沿いの緑道が計画されて いること。(3)更に, 大台北市区計画が立てられた 1932 年には, ブールバールで結ばれた同様のパークシステムが計画され，終戦 後の高雄市政府はそれを引き続いで事業化し, 今日の高雄市の骨 格を形成していることが明らかになった。

\section{文献並びに注}

1) 越沢 明 $(1987,6)$ : 台北の都市計画 1895 1945 -..-日本統治期台湾の都 市計画 : 第 7 回日本土木史研究発表会 論文集, 121-132

2 ）五島 寧 (1996)：台北の公園道路に 関する歴史的研究 : 1996 年度第 31 回 日本都市計画学会学術研究論文集, 265-270

3 ）黄武達 - 小川英明 - 鳥居徳敏 - 内藤昌 $(1992,8)$ ：日治時代高雄都市結構之分 析 : 建築学報 1992(6)，21-34，中華 民国建築学会

$4 ）$ 黄世孟 $(1985,8)$ : 台湾都市計画歴史 之初探 : 都市与計画 Vol.12(1)，120, 中華民國都市計画学会

5 ）呉欽賢 $(1988,6)$ : 日拠時期高雄市都 市発展与計画歴程之分析 : 台湾大学土 木研究所碩士論文, 145-146

6 ) 蔡厚南 $(1991,7)$ : 台湾都市公園的建 制歴程 1895 1987：国立台湾大学土 木工程学研究所博士学位論文

7 ）台湾総督府土木部 $(1911,9)$ : 打狗築 港計画一斑, 1-2, 同部

8 ）打狗内地人組合 $(1917,5)$ : 台湾南部 打狗港, 1 , 同組合

9 ）台湾総督府鉄道部（1921,4）：高雄築 港概要 大正 8 年度調，4-6，侏台湾 日々新報社

10）片山清夫編（1936,5）：大高雄建設論 と市の現勢, pp.200, 南海時報社高 雄支局

11）臨時台湾工事部 $(1908,10)$ : 打狗築港 計画一斑：(侏台湾日々新報社

12）前掲 7 ), 10-11

13）鳳山庁 $(1908,5)$ : 明治 41 年 5 月 1 日 鳳山庁報第 304 号 : 台南新報

14）前掲 2)，145-146

15）盧嘉興（1955,6）：高雄市塩田滄桑史 略：高市文物 Vol.1(2)，10-11，高

\section{雄市文献委員会}

16）田中一二・芝 忠一（1918,7）：台湾 の工業地打狗港，57-58，(粈台湾日々 新報社

17）高雄市役所（1935,2）：高雄市水道概 要, 2 , 同所

18）1915年 9 月に臨時台湾総督府工事部 打狗築港計画図

19）前掲 9 ), 7-12

20）台南庁 $(1912,3)$ : 明治 45 年 3 月 19 日 台南庁報第 738 号

21）打狗市区計画説明書は, 計画内容之計 画変更の時系列により台湾総督府土木 局が 1917 年末に出版したものと推定 した。

22）台湾総督府 $(1921,12)$ ：台湾総督府事 務成績提要 大正 9 年, pp.167, 同府

23）台㴒総督府 $(1923,3)$ : 台湾総督府事務 成績提要 大正 10 年, pp.267, 同府

24）高雄州（1921）：大正 10 年 2 月 13 日 高雄州報第 41 号

25）黄武達（1991）：台湾都市の復元的研 究, pp.123, 自費出版

26）高雄州（1923）: 大正 12 年 4 月 29 日 台湾総督府告示第 83 号，同 5 月 4 日高雄州報第 323 号

27）高雄州役所 $(1924,10)$ : 高雄州要覧, pp.166，株台湾日々新報社

28）高雄州（1924）: 大正 13 年 1 月 6 日本 多博士講演記録（場所 : 高雄第 2 小学 校): 同 3 月 29 日高雄州報第 450 号彙 報

29）高雄市役所 $(1934,12)$ : 高雄市制十周 年略誌，80-81，同市役所

30）高雄市役所 $(1933,7)$ : 高雄市勢要覧: 同市役所, pp.71の「高雄市略図」を 用いた。

31）高雄州 $(1926,12)$ : 大正 15 年 12 月 6 日 訓令第 55 号: 高雄州報号外

$32 ）$ 高雄州 $(1927,8)$ : 昭和 2 年 8 月 26 日

\section{告示第 149 号: 高雄州報号外}

33）台湾総督府 $(1939,4)$ ：台湾総督府事 務成績提要 昭和 7 年, pp.268, 同 府

34）高雄州 $(1932,10)$ : 高雄州報第 729 号

35）前掲 33), 268,273-274

36）前掲 10)， 362

37）台湾総督府 $(1941,4)$ : 台湾総督府事 務成績提要 昭和 11 年, pp.231, 同 府

38）高雄州（1936）：昭和 11 年 8 月 29 日 高雄州報第 1154 号

39）桑名次郎（1937）：高雄市都市計画概 観 : 区画整理（土地区画整理研究会） Vol.3(4), 60-61

40）前掲 10)

41）前掲 10)，1-127，岡山登喜正の䯚賞 論文を掲載

42）前掲 10），128-198，陳高昂の懸賞論 文を掲載

43）台湾総督府 $(1937,8)$ ：昭和 12 年 8 月 27 日 告示第 185 号: 総督府報第 3066 号

44）台湾総督府（1938）：昭和 13 年 11 月 26 日 台湾総督府報第 3443 号

45）台湾総督府 $(1941,8)$ : 昭和 16 年 8 月 23 日 告示第 719 号：総督府報第 4273 号

46）台湾総督府 $(1943,11)$ : 昭和 18 年 11 月 6 日 告示第 989 号: 総督官報第 479 号

47）台湾総督府 $(1941,4)$ ：台湾総督府事務 成績提要 昭和 11 年, pp.197, 同府

48）貴香 $(1955,12)$ : 高雄区鉄路之史略和 運輸：高市文物 Vol.1(4)，30-33, 高雄市文献委員会

49）台湾総督府（1937）：昭和 12 年 6 月 13 日 台湾総督府報第 3004 号

50）高雄市文献委員会 $(1956,10)$ ：高雄市 志概述篇，146-150，同会

Summary: This research is a study about the development of the city parks and open space planning of Kaohsiung during the Japanese colonial period. Through governmental documentations and reports of new discovery, we can confirm the following items: (1). Due to the starting of urban planning as a result of establishing the harbor, the earliest park was planed and was similar to that of Taipei's Yuan Shen Park, which is set at an ideal location with a nice view. (2).In 1917 the land use plan was incorporated with the park location plan. Small parks were planned adjacent to schools and green pathways were planned along riverside. (3).In 1932 Taipei and Kaohsiung City simultaneously implemented the systematic park plan, which formed the basic structure for today's City Plan of Kaohsiung City. 